\title{
THE SUCCESS OF LOCAL CONTRACTORS IN THE PROCUREMENT OF CONSTRUCTION PROJECTS IN KENDARI, SOUTH EAST SULAWESI, INDONESIA
}

\author{
M. Akbar Kurdin, La Welendo, Rifa’i Maulana \\ Halu Oleo University, Kampus Bumi Tri Dharma, Anduonohu, Kendari, Indonesia \\ Email:akbarnanang71@yahoo.com
}

\begin{abstract}
This study aims to identify the diverse formulation of the problem related to the success of winning the construction project procurement for local construction company in Kendari. The urgency of this study is to answer the factors that determine the success of local contractors in the construction project procurement process in Kendari. The method used in this study is a statistical analysis method. Dimensions are used to measure success in the procurement of construction projects in this research is the company's experience, equipment and tools, human resources, process control, reputation / achievement contractors, financial, project organization, workplace safety. Dimensions is formulated into 22 variables to be measured. From the findings of research on the variables that influence the success of winning the procurement of construction project in Kendari obtained linear regression models, namelyY $=-0,401+0,448 \mathrm{X}_{2}+$ $0,576 \mathrm{X}_{14}+0,273 \mathrm{X}_{12}$. The analysis results obtained from the dominant factors that influence the success of winning the construction procurement namely a kind of work that have been done, the project owner relationship with the contractor, and the methods and strategy implementation and control of the work to be done.
\end{abstract}

Keywords: Procurement, Construction Project, Local Contractor.

\section{INTRODUCTION}

In Indonesia, the construction projects are held generally consist of private projects and government projects. The work on the private sector is financed entirely with private funds. In the private sector, the construction business can be realized based on competitive tendering (auction) and or negotiation for the implementation of the contract. While on the public sector, because public works financed by the funds of State Budget (APBN) or Regional Budget (APBD), where accountability must be pursued carefully as possible, and must follow applicable regulations strictly because of transparency in its implementation becomes highly preferred. Type of procurement is done on both the type of project (public and private) follow the applicable system.

At any construction work that through the procurement of both in the private and government jobs generally recognize that: despite all bidders equally reliable in terms of profession, but its potential cannot be equated in the competition. In order to avoid various irregularities implementation, almost all public works are always supplied by the process of procurement through competitive tendering (procurement).

In the process of procurement of construction, will be followed by more than one contractor and one of them must be selected by the project owner as a winner, then made certain assessment. However, if the determinants of the success of winning the procurement of construction carried out by the project owner has the same view with the construction service providers follow the procurement process, especially in Kendari. Therefore, this study attempt to determine how much the opportunity of each local contractors and the influence of the factors of success in winning the procurement of construction in Kendari, seen from the perspective of local contractors in Kendari.

As an initial frameworks and to support the further research, there are few studies that have been done by other researchers are related and in accordance with the evaluation problem in selection of contractors. JS. Russell and MJ. Skibniewski (1988), in his research on "Decision Criteria in Contractor Prequalification", have been discussed in the qualification process of selecting the contractor and the factors that influence in the prequalification. Reza Febriano (2006) has found the weight rating on the tendering evaluation criteria. Meanwhile, E.J.Jaselskis (1998) has found the variables that have a high influence on the performance of the offering price in the procurement process. G.D. Holt et.al (1994) has developed a technique for the contractor prequalification namely HOLT (highlight legitimate optimum tenders) is widely used in the UK.

This study aims to identify and analyze the critical success factors for local contractors in Kendari in winning the procurement process followed.

\section{LITERATURE REVIEW \\ Implementation of Construction}

Currently, the construction industry has penetrated all fields of human life and the diversity character is reflected also in its projects. W.I Ervianto (2004) stated that the construction is a development that is not solely on the implementation of physical construction, but includes the sense of whole and complete development system. As known, the process of implementation of building construction is changing shop drawings, either engineering or architectural drawings following the rules contained in requirements or technical specifications, realized into a physical building field. According to D.S. Barrie et al, 1992, there are six basic stages which contribute to the development of a project from an idea to become a reality, the first stage is the concept and feasibility studies, followed by a phase of engineering and design, procurement, construction, start and application, and end with the operation and utilization phase.

In the process of the construction, the procurement process is one of the key parts are no less important than other activities. 


\section{Definition of Procurement}

Definition of procurement by the Project Management Institute is a process to get the goods and / or services to achieve a project, which was held outside the organization.

While definition of procurement government goods / services according to Presidential Decree No. 70 of 2012 is an activity to obtain goods / services by government institutions that process starting from planning needs until completion of all activities to obtain goods / services. Procurement is a series of activities to provide goods / services by creating healthy competition among providers of goods / services that are equivalent and eligible, based on the certain methods and procedures those are defined and followed by parties who related obey the principle that elected the best provider.

\section{Contractor Selection System}

After the software such as an auction package with all complementary documents readily available, immediately followed by activities of selecting a contractor. In some situations the project owner prefers to limit the number of contractors for the selection process for the preparation of pre-qualification list.

According to the Presidential Decree number 54 of 2010, to determine the procurement system which includes auction method, the method of submitting the tender document, the method of the tender evaluation, should consider the type, characteristic and value of the goods / services as well as site conditions, the interests of society and the number of providers of goods / services exist.

In Indonesia, in particular the procurement of construction services for projects organized by the government refers to the specified provision in the Presidential Decree. For the purposes of the procurement of construction services are divided into 5 ways, namely public auction, limited auction, direct election, direct appointment, and self-management.

According to Presidential Decree No. 70 of 2012, in the selection of providers of goods / services chartering can be selected method of submitting tender documents based on the type of goods / services to be held include a) one cover method; b) two covers method; and c) two-stage method. As for the tender evaluation method using a) fall system, which consists of the administrative evaluation, technical evaluation and price evaluation; and b) value system.

\section{Contractor Selection Process}

Contractor selection process is a series of events that began with identify the contractor services purpose by the owner, prepare a package of procurement until the signing of a contract for the physical implementation of the project. So in selection of contractors should put people in the right position. The scope of the contractor procurement process consists of the following steps: a) prequalification; b) the tender; c) pre-implementation project; d) the implementation of the project.

\section{MATERIAL AND METHODS}

In this study, the variables used are variables related to aspects of the determination of success for local contractors in the procurement process of government construction projects.

The given model will be developed with identify the variables and validate them. Validation of the variables is done to the respondents who have experience, knowledge and expertise in the field of government procurement management of construction projects. Validation of this variable aim to obtain research variables, before distributed to the respondents. The dependent variable of this study (Y) is the probability of success of winning the procurement, while for the independent variable in this study consists of several variables incorporated in 5 dimensions, namely a) the dimensions of the experience of companies consisting of a variable number of jobs in a year (X1), the work of its kind ever conducted (X2), the number of procurement projects followed in one year (X3), the experience of the contractor (X4), the level of technology that is done (X5); b) the dimensions of equipment and tools are composed of variable completeness of the availability of various types of tools / equipment / construction fittings (X6), equipment to be used (X7); c) the dimensions of human resources consisting of variable availability, level of education and field staff (X8), the availability, level of education and experience design staff (X9), certified experts / skilled (X10); d) control process, consisting of a variable control of the work program to be performed (X11), methods and strategies for implementation and control of the work to be performed (X12), the material selection process to be performed (X13); e) dimensions of reputation / achievement contractors consisting of a variable relationship between the project owner and the contractor, (X14), Frequency won previous tenders (X15); f) dimensions of financial consisting of a bank reference variable (X16), the contractor's ability to meet financial obligations by converting assets into cash (X17); g) the dimensions of the project organization consists of variable communication system in the project (X18), the control procedures of the working drawings (x19), supervision / monitoring (X20); h) dimensions of work safety that consists of the company work safety policy variable (X21), participation in the labour insurance (X22).In a simple regression model to describe the relationship model between the probability of winning a procurement $(\mathrm{Y})$ and the variables determining the success of winning procurement $(\mathrm{X})$, namely:

$$
Y=\beta_{0}+\beta_{1} * X_{1}+\beta_{2} * X_{2}+\ldots \ldots+\beta_{22} * X_{22}
$$

Which:

$Y=$ the probability of winning a procurement

$X_{1}, X_{2} \ldots X_{22}=$ the variables determining the success of winning procurement

$\beta_{0} \quad=$ constants

$\beta_{1,} \beta_{2 \ldots} \beta_{22}=$ regression coefficients

The research model can be seen from the figure below: 
PROBABILITY OF

SUCCESS ( $Y$ )

\begin{tabular}{|c|c|c|c|c|c|c|c|}
\hline$\Gamma$ & 1 & 1 & 1 & $T$ & 1 & $T$ & $\longrightarrow$ \\
\hline $\begin{array}{c}\text { company } \\
\text { experience }\end{array}$ & $\begin{array}{l}\text { equipment } \\
\& \text { tools }\end{array}$ & $\begin{array}{l}\text { human } \\
\text { resources }\end{array}$ & $\begin{array}{l}\text { process } \\
\text { control }\end{array}$ & $\begin{array}{l}\text { reputation of } \\
\text { contractors }\end{array}$ & financial & $\begin{array}{c}\text { project } \\
\text { organization }\end{array}$ & $\begin{array}{c}\text { workplace } \\
\text { safety }\end{array}$ \\
\hline$-\quad x 1$ & $-\times 6$ & $-x 8$ & X11 & $-x 14$ & $-\times 16$ & $-\mathrm{X} 18$ & $-\times 21$ \\
\hline$-\quad \times 2$ & $\leftarrow \quad x 7$ & X9 & X12 & $\leftarrow \times 15$ & L X17 & - X19 & $\leftarrow \quad \times 22$ \\
\hline$-x 3$ & & $-\times 10$ & X13 & & & $\leftarrow \times 20$ & \\
\hline
\end{tabular}

Figure 1: Research Model

\section{RESULT AND DISCUSSION}

Data Analysis

The samples which are used as many as 100 local contractors in Kendari who had joined in BPC Gapensi of Kendari. Respondents are manager contractors (directors). The result of survey that have been done, obtained characteristic of local contractors in Kendari, i.e:

Table 1: Characteristic of Local Contractors in Kendari

\begin{tabular}{clcc}
\hline \multirow{2}{*}{ No } & \multicolumn{2}{c}{ Characteristic } & \multirow{2}{*}{ Percentage } \\
\cline { 2 - 3 } & \multicolumn{1}{c}{ Criteria } & Dominant & \\
\hline 1 & $\begin{array}{l}\text { Level of } \\
\text { education }\end{array}$ & Bachelor & $56 \%$ \\
\hline 2 & Experience & $5-10$ years & $42 \%$ \\
\hline
\end{tabular}

From table 1 above, shows that local contractors in Kendari are dominated by contractors with bachelor education level with dominant experience about 5-10 years.

From 22 variables which are used to analyze success factors of local contractors within procurement in construction, conducted correlation analysis toward probability of winning procurement and obtained 15 variables which have dominant category to show relation between those variables with probability of winning procurement.

Table 2: Research Variables

\begin{tabular}{clc}
\hline Variable & \multicolumn{1}{c}{ Explanation } & $\begin{array}{c}\text { R } \\
\text { (Correlati } \\
\text { on) }\end{array}$ \\
\hline $\mathrm{X} 11$ & $\begin{array}{l}\text { Program control of the } \\
\text { work to be performed }\end{array}$ & 0,901 \\
\hline $\mathrm{X} 2$ & $\begin{array}{l}\text { Similar work was ever } \\
\text { done }\end{array}$ & 0,855 \\
\hline $\mathrm{X} 4$ & Contractor experience & 0,816 \\
\hline $\mathrm{X} 12$ & $\begin{array}{l}\text { Methods and strategies } \\
\text { for implementation and } \\
\text { control of the work to } \\
\text { be performed }\end{array}$ & 0,815 \\
\hline $\mathrm{X} 13$ & $\begin{array}{l}\text { Material selection } \\
\text { process will be done }\end{array}$ & 0,801 \\
\hline $\mathrm{X} 21$ & Safety company policy & 0,792 \\
\hline
\end{tabular}

\begin{tabular}{|c|c|c|}
\hline X6 & $\begin{array}{l}\text { Completeness the } \\
\text { availability } \\
\text { of various types } \\
\text { of tools / equipment / c } \\
\text { onstruction equipment }\end{array}$ & 0,762 \\
\hline X5 & $\begin{array}{l}\text { The level of } \\
\text { technology conducted }\end{array}$ & 0,737 \\
\hline X14 & $\begin{array}{l}\text { Contractor relationship } \\
\text { with the project owner }\end{array}$ & 0,721 \\
\hline X19 & $\begin{array}{l}\text { Control } \\
\text { procedures for shop } \\
\text { drawing }\end{array}$ & 0,718 \\
\hline X17 & $\begin{array}{l}\text { Contractor's ability to } \\
\text { meet financial } \\
\text { obligations by } \\
\text { converting assets into } \\
\text { cash }\end{array}$ & 0,703 \\
\hline X8 & $\begin{array}{l}\text { The availability, level } \\
\text { of education and field } \\
\text { staff }\end{array}$ & 0,699 \\
\hline X10 & $\begin{array}{l}\text { Certificates of } \\
\text { professional / skilled }\end{array}$ & 0,696 \\
\hline X18 & $\begin{array}{l}\text { The communication } \\
\text { system in the project }\end{array}$ & 0,635 \\
\hline X20 & $\begin{array}{l}\text { Supervision / } \\
\text { Monitoring }\end{array}$ & 0,603 \\
\hline
\end{tabular}

Multiple linear regression analysis performed on a combination of independent variables that have 15 variables and searched which has the largest Adjusted $\mathrm{R}^{2}$ obtained:

$Y=-0,401+0,448 X_{2}+0,576 X_{14}+0,273 X_{12}$

Which:

$\mathrm{X}_{2}=$ Similar work was ever done

$\mathrm{X}_{14}=$ Contractor relationship with the project owner

$\mathrm{X}_{12}=$ Methods and strategies for implementation and control of the work to be performed

$\mathrm{Y}=$ Probability of success winning the auction

Furthermore, based on the analysis results in the regression equation can be graphed on a linear model as shown 


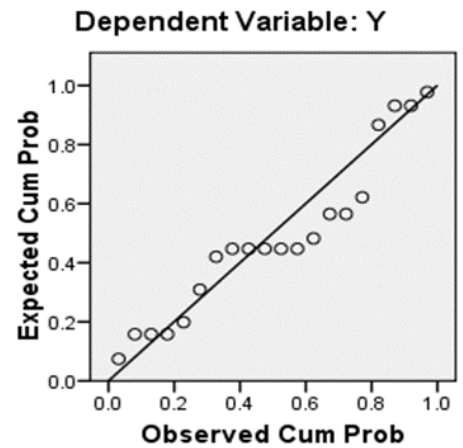

Figure 2. Normal P-P Plot of Regression Standardized Residual

Test Models

a. Adjusted $\mathbf{R}^{2}$ Test

Result of test adjusted $\mathrm{R}^{2}$ can be shown on table 3 :

Table 3: Result of Test $\mathrm{R}^{2}$

\begin{tabular}{cc}
\hline Regression Model & Adjusted $\mathbf{R}^{2}$ Value \\
\hline $\mathrm{Y}=-0,401+0,448 \mathrm{X}_{2}+$ & 0,913 \\
$0,576 \mathrm{X}_{14}+0,273 \mathrm{X}_{12}$ & \\
\hline
\end{tabular}

b. F - test

Result of F-test can be shown on table 4:

Table 4: Result of F-Test

\begin{tabular}{|c|c|c|c|}
\hline $\begin{array}{l}\text { Regression } \\
\text { Model }\end{array}$ & $\begin{array}{l}\text { S Significant } \\
\text { Value }\end{array}$ & $\begin{array}{l}\text { F Value } \\
\text { (Count) }\end{array}$ & $\begin{array}{l}\text { F Table } \\
\text { Value }\end{array}$ \\
\hline $\begin{array}{c}\mathrm{Y}=-0,401+ \\
0,448 \mathrm{X}_{2}+ \\
0,576 \mathrm{X}_{14}+ \\
0,273 \mathrm{X}_{12}\end{array}$ & 0 & 67,1 & 3,06 \\
\hline
\end{tabular}

From the test results table F-test can be found that $\mathrm{F}$ count value resulting from the above model is larger than $\mathrm{F}$ table, this result means that the independent variable on each of the above mentioned models simultaneously influence on the probability of success winning procurement.

\section{c. T-test}

Result of T-test can be shown on table 5:

Table 5: Result of T-test

\begin{tabular}{cccc}
$\begin{array}{c}\text { Determinant } \\
\text { Variable }\end{array}$ & $\begin{array}{c}\text { Significant } \\
\text { Value }\end{array}$ & $\begin{array}{c}\text { T Count } \\
\text { Value }\end{array}$ & $\begin{array}{c}\text { T Table } \\
\text { Value }\end{array}$ \\
\hline $\mathbf{X} 2$ & 0 & 6,270 & 2,093 \\
\hline $\mathbf{X 1 4}$ & 0 & 4,289 & 2,093 \\
\hline $\mathbf{X 1 2}$ & 0 & 2,586 & 2,093 \\
\hline
\end{tabular}

From Table 5 above resulting count value $\mathrm{T}$ is generated each variable in each regression model larger than $\mathrm{T}$ table, this means that each independent variable in each model have partial effect on the probability of success winning procurement.

\section{d. Auto Correlation}

Based on the result of auto correlation test, DurbinWatson value can be shown on table 6 below:

Table 6: Result of Auto Correlation Test

\begin{tabular}{|c|c|c|c|c|c|}
\hline $\begin{array}{l}\text { Mode } \\
\quad l\end{array}$ & $\mathbf{R}$ & $\mathbf{R}^{2}$ & $\begin{array}{c}\text { Adjuste } \\
\text { d R R }^{2}\end{array}$ & $\begin{array}{c}\text { Std. } \\
\text { Error } \\
\text { of the } \\
\text { Estimat } \\
\text { e }\end{array}$ & $\begin{array}{c}\text { Durbin } \\
- \\
\text { Watso } \\
\text { n }\end{array}$ \\
\hline 1 & $\underset{\mathrm{a}}{0,876}$ & $\begin{array}{c}0,76 \\
7\end{array}$ & 0,754 & 0,128 & \multirow{3}{*}{1,709} \\
\hline 2 & $\underset{\mathrm{b}}{0,946}$ & $\begin{array}{c}0,89 \\
6\end{array}$ & 0,883 & 0,088 & \\
\hline 3 & $\underset{\mathrm{c}}{0,962}$ & $\begin{array}{c}0,92 \\
6\end{array}$ & 0,913 & 0,076 & \\
\hline
\end{tabular}

a. Predictors: (Constant), X2

b. Predictors: (Constant), X2, X14

c. Predictors: (Constant), X2, X14, X12

d. Dependent Variable: $\mathrm{Y}$

From Table 6 can be found that the value of the Durbin-Watson for the linear regression model is 1,709. Thus there is no auto correlation means, so the model is quite stable in this study.

\section{CONCLUSION}

From the research findings obtained most dominant variable in determining the success of local contractors to winning procurement in construction i.e similar work was ever done (X2), contractor relationship with the project owner (X14), methods and strategies for implementation and control of the work to be performed (X12), with models of the probability of success is $\mathrm{Y}=-0,401+0,448 \mathrm{X}_{2}+0,576 \mathrm{X}_{14}+0,273 \mathrm{X}_{12}$. From the survey scale influence on these three variables, found that the local contracting company in Kendari has a very high chance of success in its participation in the procurement process of construction projects in Kendari. However, in this study, the chances of success winning procurement in construction is still limited to local competitive bidding, so for future research, it is advisable to test variables such success in international competitive bidding, considering that the current local 
contractors must be prepared to face global competition in dealing with ASEAN Economic Community (AEC).

\section{REFERENCES}

[1] D.S. Barrie, B. C. Paulson. 1992. Professional Construction Management. McGraw-Hill Publishing Company

[2] E.J.Jaselskis, A. Talukhaba. 1998 Bidding Consideration in Developing Countries. Journal of Construction Engineering and Management. Volume 124

[3] Decree of the President of the Republic of Indonesia Number 80 Year 2003 on Guidelines for Procurement of Government Goods / Services

[4] G.D. Hold, P.O. Olomolaiye, F.C. Harris. 1994. Evaluating Performance Potential in the Selection of Construction Contractors. Engineering. Construction and Architectural Management

[5] Government Regulation No. 85 Year 2006 on Guidelines for Procurement of Government Goods / Services Sixth Amendment on Presidential Decree No. 80 of 2003

[6] I. Dipohusodo. 1996. Manajemen Proyek Dan Konstruksi Jilid 1. Penerbit Kanisius, Yogyakarta.

[7] JS. Russell, MJ. Skibniewski. 1988. Decision Criteria in Contractor Prequalification. Journal Of Construction Engineering And Management vol.4, No.2, pp. 148-164

[8] Regulation of the President of the Republic of Indonesia Number 54 of 2010 Concerning the Procurement of Goods / Services

[9] Presidential Decree No. 70 of 2012 On the second amendment to the Presidential Decree Number 54 Year 2010 concerning Procurement of Government Goods and Services

[10] Reza Febriano. 2006. Determination of Weight Assessment Work Bid Evaluation Criteria in Works in PT Jasa Marga (Persero) Using AHP. Thesis Graduate Program in Engineering. Indonesia University

[11] W.I Ervianto. 2004. Manajemen Proyek Konstruksi. Penerbit Andi. Yogyakarta 